\title{
The Relationship Between Compensation, Motivation, And Earnings Management
}

Wendy W. Achilles, Ph.D., North Carolina Wesleyan College, USA

Jennifer Blaskovich, Ph.D., University of Nebraska - Omaha, USA

Terence J. Pitre, Ph.D., University of St. Thomas, USA

\begin{abstract}
Regulators and investors remain concerned with earnings management and its effect on the reliability of accounting information. Agency literature suggests that a lack of compensation incentives (i.e., bonus payments) can decrease-but not completely eliminate-earnings management behavior, while theory from psychology suggests that individuals may be motivated to manage earnings, regardless of compensation. Consequently, we examine how compensation incentives and motivation (intrinsic versus extrinsic) affect earnings management behavior. We hypothesize and find that when compensation is linked to firm performance, managers make income increasing (decreasing) decisions when current earnings are below (above) analysts' forecasts. We find that in the absence of compensation incentives, managers make earnings increasing decisions when current earnings are below analysts' forecasts, but they do not make earnings decreasing decisions when current earnings are above analysts' forecasts. Finally and most importantly we show that managers who possess strong extrinsic motivation are more likely to manage earnings upwards to reach targets - in the absence of compensation-possibly because it helps satisfy their competitive spirit and need for recognition. However when current earnings are above the target (analysts' forecasts), managers are not compelled to manage earnings as this drive has already been satisfied.
\end{abstract}

Keywords: Earnings Management; Compensation; Motivation; Extrinsic Motivation

\section{INTRODUCTION}

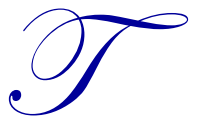

he issue of earnings management continues to be of much interest to regulators, investors, and managers in the U.S. Prior literature has documented that managers frequently adjust earnings to meet the various thresholds established by analysts' quarterly and annual earnings estimates (Burgstahler and Dichev 1997; Defond and Park 1997; Degeorge et al. 1999). Specifically these studies find that managers try to avoid (1) reporting losses, (2) decreases in earnings from the prior year, and (3) earnings that fall short of consensus analysts' forecast. Earnings management can exist for several reasons, including capital market pressure, compensation incentives, and cognitive incentives. While we acknowledge the importance of capital market pressure, this research addresses the latter two reasons for earnings management. Specifically, this research investigates if cognitive motivation can explain management decision making when compensation incentives are absent.

Literature related to incentive compensation documents that managers use discretionary accruals to manage earnings to achieve their bonus levels (i.e., Cheng and Warfield 2005; Matsunaga and Park 2001; Healy 1985) and increase stock option value (i.e., Baker et al. 2009). Carter, Lynch, and Zechman (2006) however, found that firms that lowered the contract incentives to manage earnings lessened but did not completely mitigate earnings management behavior. Thus, although compensation is related to earnings management, the absence of linked incentives does not necessarily eliminate the behavior. The main focus of this research is to investigate if cognitive motivation can explain management decision making when compensation incentives are absent. 
The idea that cognitive incentives motivate individual behavior is well established in the psychology literature. Intrinsically-motivated individuals may engage in an activity in order to feel self-determined or challenged, even when there is no direct reward. The reward for engagement is internal and manifests in the individual's personal feelings about him or herself (Deci 1976). Extrinsically-motivated individuals are driven by competition, evaluation, recognition, or monetary rewards (Amabile et al. 1994). In this study, we suggest that meeting or beating analysts' forecasts may encourage the competitive spirit or act as a measure of evaluation and recognition for an extrinsically-motivated individual, in the absence of compensation incentives.

The primary objective of this research is to examine the triangular relationship between compensation incentives, earnings management, and cognitive incentives. We report the results of a 2 x 2 between-subjects design experiment where the between-subjects variables are analysts' forecasts (above or below current earnings) and compensation incentives (bonus or no bonus). Their managerial decision involved the selection of a revenue recognition scheme, from among five choices, related to fees collected on yearly admission passes. After completing the experiment, participants were also required to answer demographic questions and a personality trait questionnaire. The first part our analysis allows us to document the presence of earnings management while the latter (personality trait questionnaire) allows us to determine if internal motivation helps explain earnings management behavior in the absence of compensation incentives. Our results indicate that participants in the bonus condition made income increasing (decreasing) decisions when the current earnings were below (above) analysts' forecasts. Participants in the no bonus condition managed earnings upwards when analysts' forecasts were above current earnings, but chose a neutral or "do nothing" strategy, when analysts' forecasts were below current earnings. We find that participants with high extrinsic motivation were more likely to manage earnings upwards, perhaps in order to satisfy their need for competition, recognition, and evaluation, while those with high intrinsic motivation did not manage earnings. Jointly taken, these results suggest that the removal of compensation incentives alone is not sufficient to deter earnings management as individual motivational orientation will also contribute to the behavior.

This research makes several contributions. First, the overwhelming majority of research on earnings management is conducted on aggregate archival data. Our research shows that managerial discretion - often studied at the industry or firm level (e.g., Bloom and Milkovich, 1995; Finkelstein and Boyd, 1998; Zajac and Westphal, 1994) - can be understood further by experimental examination at the individual level. Second, this study answers the call of Healy and Wahlen (1999) for research that focuses on identifying factors that may cause or limit earnings management. Third, this research extends the extant compensation/earnings management literature that has documented the existence of a relation between CEO compensation and earnings benchmarks (e.g., Matsunaga and Park 2001; Cheng and Warfield 2005; Healy 1985). We add to this literature by documenting how individual characteristics can influence that relationship.

The remainder of this paper is organized as follows: Section II contains the literature review and hypotheses development; Section III contains the experimental design; Section IV contains the empirical results and Section V offers conclusions.

\section{LITERATURE REVIEW AND HYPOTHESES DEVELOPMENT}

Managerial discretion is a function of both the context (industry/environment and organization) and the individual factors that help to characterize managers and management style (Hambrick and Finkelstein, 1987). Consistent with this conceptualization, we investigate whether discretion regarding accounting treatment is affected by contextual factors (firm performance relative to analysts' forecasts and compensation schemes) and personal characteristics (individual motivation).

\section{Earnings Management}

Earnings management is defined as when managers use judgment in financial reporting and in structuring transactions to alter financial reporting to either mislead stakeholders about the underlying economic performance of the company or to influence contractual outcomes that depend on accounting numbers (Schipper 1989). Historically, the literature on earnings management and the role of accruals has been well documented (e.g. Brown 
and Caylor 2005; Dechow et al. 2003; Bartov et al. 2002; Kasznik and McNichols 2002; Healy and Whalen 1999; Burgstahler and Dichev 1997).

Firms engage in earnings management in order to: (1) report profits (2) meet/exceed previous year's benchmark relative to the prior comparable period and (3) meet/exceed a benchmark relative to analysts' earnings projections (Degeorge et al. 1999). Prior research has documented that a primary incentive for earnings management is compensation (e.g., Das et al. 2009; Goldman and Slezak 2006). Managers use discretionary accounting accruals to arrive at earnings levels that maximize their bonuses. ${ }^{1}$ This may result in income increasing accruals to meet the benchmark or income decreasing accruals when managers choose to reserve 'excess' earnings for a later, leaner reporting period (Das et al. 2009). Additionally, managers may engage in income decreasing accruals to create a lower hurdle or benchmark for upcoming periods. Although this concept has been substantiated in prior research, we offer and test hypotheses to confirm this behavior for two main reasons. First, because the vast majority of earnings management research has been conducted on archival data, we test it in an experimental setting. Second, we confirm the role of compensation on earnings management in order to compare it to behavior in the absence of compensation. Accordingly:

H1a: In the presence of compensation incentives and when current earnings are below analysts' forecasts, managers will manage income upwards.

H1b: In the presence of compensation incentives and when current earnings are above analysts' forecasts, managers will manage income downwards.

Although constraining this behavior may be a goal of regulators (e.g., Levitt 1998), severing the link between earnings and compensation is not likely to be successful. Prior research has documented that a decrease in compensation incentives lessens, but it does not mitigate entirely, earnings management (e.g., Carter et al. 2006). Research from psychology and sociology provides a theoretical basis for understanding why the absence of compensation incentives may not completely eliminate earnings management. Although the traditional economic theory of motivation and behavior rests upon the utility of economic rewards, social psychology literature recognizes internal motivation as a central aspect in cognitive behavior (Rawsthorne and Elliot, 1999). Most of this literature has focused on intrinsic motivation, defined as interest in or pursuit of an activity for its own sake or for personal satisfaction (Deci and Ryan 1985). The concept has garnered considerable research attention and is widely recognized by social psychologists as a determinant of behavior and achievement (Rawsthorne and Elliot1999; Koestner et al. 1987; Deci and Ryan 1985).

Although intrinsic motivation has received much of the attention, a number of researchers have expanded the study of internal motivation to include extrinsic motivation, particularly in the workplace (e.g., Amabile et al. 1976; Amabile et al.1994). This line of study suggests that individuals may be either intrinsically- or extrinsicallymotivated to engage in a particular behavior. Extrinsically-oriented managers are driven by not only the pursuit of monetary rewards, but also by a need for recognition, evaluation, and/or competition with others (Amabile et al. 1994).

In the absence of compensation incentives, extrinsic motivation could lead to earnings management as managers strive to meet the evaluation level or competitive yardstick created by reporting thresholds (i.e., analysts' forecasts). Meeting or beating analysts' forecasts also offers an opportunity for recognition amongst peers and avoidance of perceived 'failure' (Graham et al. 2006). When current earnings are below analysts' forecasts managers can be expected to manage income upwards. We propose that extrinsic motivation explains upward earnings management in the absence of compensation incentives. However, when current earnings are above

\footnotetext{
${ }^{1}$ Much of this research stems from the agency theory literature, which considers the decisions of a single decision maker, and makes assumptions about their behavior (e.g., single risk-averse manager who reports to one or more owners). Additionally, the discussion and the empirical testing is conducted primarily at the firm level where data are aggregated across many decision makers who face different specific bonus plans and financial situations (e.g., Watts and Zimmerman, 1978; Hagerman and Zmijewski, 1979; Holthausen, 1981; Zmijewski and Hagerman, 1981; Collins et al. 1981; Bowen et al. 1981; Healy, 1985).
} 
analysts' forecasts, managers may view the target goal as having been met and, in the absence of compensation, are less likely to manage income downwards. Stated formally:

H2a: In the absence of compensation incentives and when current earnings are below analysts' forecasts, managers will manage income upwards.

H2b: In the absence of compensation incentives and when current earnings are above analysts' forecasts, managers will not manage income downwards.

H3: Managers who manage earnings upwards in the absence of compensation incentives are more likely to have high extrinsic motivation than those managers that do not manage earnings upwards.

\section{EXPERIMENTAL DESIGN}

In our experiment, managers are asked to select one of five plans for revenue recognition regarding the sale of yearly theme park passes. Firm income may be increased or decreased dependent on the method of revenue recognition chosen by the manager. Compensation incentive and consensus analysts' forecasts (hereafter, 'forecast') were manipulated between subjects. Our experimental approach is similar to the Cloyd et al. (1996) study of the effects of managers' incentives at both public and private firms on tax and book conformance and the Kennedy et al. (1998) study of the effects of managers' incentives on alternative liability disclosures. Our task is most similar to that used by Hunton et al. (2006) who study the effects of transparency on experienced managers' earnings management behavior. While the experimental design is a $2 \times 2$, the primary focus of this research is to provide insight as to whether managers are motivated intrinsically or extrinsically when they manage earnings upwards or downwards. Consequently the analysis focuses on a subset of the cells data rather than a traditional cell by cell analysis.

\section{Participants}

Our participants consisted of 90 MBA students enrolled in the graduate program at a large University. The MBA program is geared toward individuals with current, full-time employment in the business community, and the majority of participants $(95.6 \%)$ in the sample are currently working (mean $=5.3$ years, range $=0-23$ years). A variety of industries are fairly evenly represented, including manufacturing, retail, financial, technology, communications, health care, and governmental/not-for-profit. Gender split is $60 \%$ male and $40 \%$ female. Students were given ten points extra credit for their participation in the experiment.

\section{Task}

The case materials asked participants to assume the role of a financial executive for a publicly-owned theme park that was followed by analysts. Those in the bonus condition are told that their compensation includes a fixed $10 \%$ bonus if they meet or beat the forecast. In this scenario, the bonus serves as extrinsic motivation. ${ }^{2}$ Participants are told it is May 20xx and they are preparing their monthly financial statements. The theme park has recently sold $\$ 400,000$ in yearly passes. The yearly passes can be used at anytime over the next year. They are then presented with five alternative revenue recognition plans along with simplified income statements to show the effects of each plan on firms' earnings. Each of the five plans results in different levels of overall earnings for the firm. Participants are made aware of the forecast for the period and then asked to recommend which of the revenue recognition plans they prefer. Finally, participants complete demographic questions and the Work Preference Inventory (WPI), an empirically validated, 30-question instrument (Amabile et al. 1994) to assess motivational orientation. The WPI result is the calculation of two scores, one for intrinsic (15 questions) and one for extrinsic (15 questions) motivation. Questions are answered on a scale of 1 (never, or almost never, true of me) to 4 (always, or

\footnotetext{
${ }^{2}$ It is worth noting that it is possible that the prospect of keeping one's job via meeting/beating the forecasts could be viewed as extrinsic motivation. This would bias the results against finding any main effects of compensation or interaction effects of compensation and forecasts. Results suggest however that there were main effects of compensation and an interaction between compensation and forecasts.
} 
almost always, true of me). A score of 1 represents extrinsic motivation while a score of 4 represents intrinsic motivation.

\section{Experimental Design and Variables}

In our $2 \times 2$ between-subjects design, we indicate that the controller has determined preliminary earnings to be $\$ 1,500,000$ (constant across conditions). Reporting frequency is also held constant (monthly) across conditions. We manipulate both the compensation incentive of the manager (bonus or no bonus) and the forecast (above or below current earnings). The five alternative plans are constant across conditions and offer participants a choice of revenue recognition decisions that result in monthly earnings between $\$ 1,300,000$ (plan 1) and \$1,700,000 (plan 5). The participants are informed that all of the five revenue recognition plans will permit the firm to meet their quarterly target. The dependent variable is the plan (1-5) reported by managers.

\section{RESULTS}

$\mathrm{H} 1$ and $\mathrm{H} 2$ test for the presence of earnings management in general, while $\mathrm{H} 3$ specifically examines whether intrinsic or extrinsic motivation affects whether managers engage in earnings management or not. Consequently, $\mathrm{H} 3$ provides us with the unique contribution of this research. Table 1 reports the means and standard deviations for the recognition plan selected across the four conditions. A choice of revenue recognition plans 1 or 2 is indicative of an earnings decreasing strategy, plan 3 represents a neutral strategy (report earnings as \$1,500,000), and a choice of plans 4 or 5 is indicative of an earnings increasing strategy. When preliminary earnings $(\$ 1,500,000)$ were below the forecast $(\$ 1,600,000)$, participants followed an earnings increasing strategy. The mean selection of revenue recognition plan is 4.05 and 3.86, for bonus and no bonus conditions, respectively. This signifies that overall, participants, on average, chose a revenue recognition plan to raise earnings above the controller's preliminary estimate of $\$ 1,500,000$ (or, plan 3). When earnings were above the forecast $(\$ 1,400,000)$, participants in the bonus condition followed an earnings decreasing strategy (mean=2.09). However, in the no bonus condition, participants appeared to follow a 'do nothing' strategy and chose the revenue recognition plan that matched the controller's earnings estimate (mean=2.92). These results indicate preliminary support for hypotheses 1 and 2 .

Table 1

Earnings Resulting from the Selection of a Revenue Recognition Plan $\operatorname{Mean}^{\mathrm{a}}$ (SD) Compensation Incentive

\begin{tabular}{|c|c|c|c|}
\hline \multirow[b]{2}{*}{ Analysts' Forecasts } & \multicolumn{2}{|c|}{ Compensation Incentive } & \multirow[b]{2}{*}{$\begin{array}{c}\text { Main Effect of } \\
\text { Analysts' Forecasts }\end{array}$} \\
\hline & Bonus & No Bonus & \\
\hline$=\$ 1,600,000$ & Cell $1, n=22$ & Cell $3, n=22$ & $\mathrm{n}=44$ \\
\hline Above Preliminary Earnings of $\$ 1,500,000$ & $4.05(0.79)$ & $3.68(0.48)$ & $3.86(0.67)$ \\
\hline$=\$ 1,400,000$ & Cell 2, $n=22$ & Cell 4, $n=24$ & $\mathrm{n}=46$ \\
\hline Below Preliminary Earnings of $\$ 1,500,000$ & $2.09(0.29)$ & $2.92(0.28)$ & $2.52(0.51)$ \\
\hline Main Effect of & $\mathrm{n}=44$ & $\underline{n}=46$ & $\underline{n}=90$ \\
\hline Compensation Incentive & $3.07(1.15)$ & $3.28(0.54)$ & $3.18(0.89)$ \\
\hline
\end{tabular}

${ }^{\mathrm{a}}$ Scale $1-5$, representing earnings of: $1=\$ 1,300,000 ; 2=\$ 1,400,000 ; 3=\$ 1,500,000 ; 4=\$ 1,600,000 ; 5=\$ 1,700,000$.

Next we conduct an ANOVA where the dependent variable is the revenue recognition plan reported by participants and the independent variables are forecast (above or below current income) and compensation incentive (bonus or no bonus). As shown in Table 2 (Panel A), the interaction term is significant $(p<0.001){ }^{3}$ Accordingly, we report direct tests in Table 3 (Panel B). Hypotheses 1a examines if, in the presence of compensation incentives, managers manage earnings upward to meet the forecast $(\$ 1,600,000)$. Participants' mean selection of revenue recognition plans (4.05; recall that revenue recognition plan 4 results in earnings of $\$ 1,600,000)$ is significantly higher than the revenue recognition plan of 3 (which represents pre-managed earnings of $\$ 1,500,000)(t=6.24$, $p<0.001)$. Hypotheses $1 \mathrm{~b}$ examines if, in the presence of compensation incentives, managers manage earnings downward to meet the forecast $(\$ 1,400,000)$. The mean of selected plans $(2.09$, recall that revenue recognition plan

\footnotetext{
${ }^{3}$ All reported p-values are two-sided. 
2 results in earnings of $\$ 1,400,000)$ is significantly lower than $3(t=-14.5, p<0.001)$. Accordingly, both hypotheses $1 \mathrm{a}$ and $1 \mathrm{~b}$ are confirmed.

Table 2

Analysis of Revenue Recognition Plan by Treatment Conditions Dependent Variable: Earnings

\begin{tabular}{|c|c|c|c|c|}
\hline \multicolumn{5}{|c|}{ Panel A: Test of between-subjects effects } \\
\hline Source & $\underline{\text { Sum of squares }}$ & $\underline{\mathrm{df}}$ & $\underline{F}$ & Sig. of $F^{*}$ \\
\hline \multicolumn{5}{|l|}{ Main effects: } \\
\hline Forecast $^{\mathrm{a}}$ & 4.55 & 1 & 167.43 & 0.001 \\
\hline Compensation $^{\mathrm{b}}$ & 1.20 & 1 & 4.83 & 0.031 \\
\hline \multicolumn{5}{|l|}{ Interaction: } \\
\hline Forecast x Compensation & 7.95 & 1 & 31.97 & 0.001 \\
\hline Residual & 21.38 & 86 & & \\
\hline \multicolumn{5}{|l|}{ Panel B: Tests of Hypotheses } \\
\hline & & & t-stat & $\underline{\text { Sig. of } \mathrm{t}^{*}}$ \\
\hline H1a: Cell $1>3.0(\$ 1,500,000)$ & & & $\overline{6.24}$ & 0.001 \\
\hline H1b: Cell $2<3.0(\$ 1,500,000)$ & & & -14.5 & 0.001 \\
\hline H2a: Cell $3>3.0(\$ 1,500,000)$ & & & 6.71 & 0.001 \\
\hline H2b: Cell $4>3.0(\$ 1,500,000)$ & & & -1.45 & 0.162 \\
\hline
\end{tabular}

Next we examine the actions of participants in the absence of incentive bonuses. We find that participants manage earnings upwards when current earnings are below forecast, but do not manage earnings downwards when earnings are above the forecast. In Table 1, we report that the mean recognition plan selected was 3.68 when earnings were below forecast of $\$ 1,600,000$, indicating an earnings increasing strategy. As predicted in H2a, managed earnings were significantly higher than the pre-managed earnings of $\$ 1,500,000 \quad(t=6.71, p<0.001)$. Alternatively, when earnings were above the forecast of $\$ 1,400,000$, the mean recognition plan selected was 2.92 , indicating an earnings decreasing strategy. Table 2 (Panel B) reports that managed earnings were not significantly different from pre-managed earnings of $\$ 1,500,000$ (i.e., 2.92 is not significantly different from $3 ; t=-1.45$, one sided $p=0.163)$. This result supports H2b.

H3 suggests that managers who manage earnings upwards in the absence of incentive bonuses are more likely to have high extrinsic motivation than those who do not manage upwards. For this analysis, we analyze the results of one cell, (no bonus, forecast above). We separated the responses into two categories; managed earnings and unmanaged earnings. Using the results of the personality trait inventory, we calculate an intrinsic motivation (IScore) and extrinsic motivation score (X-Score) for participants in each of the two groups. We then compare the scores for testing of H3. Recall that scores closer to 1 represent higher extrinsic motivation and scores closer to 4 represent higher intrinsic motivation. Table 3 shows managers who chose to manage earnings upwards, absent compensation incentives, had greater X-Scores ( 2.23 vs 2.96$)$ than those managers that did not manage upwards $(t=4.41, p<0.001)$. Additionally, the I-Score scores for participants were not significantly different between those who managed and those who did not manage earnings upward $(t=0.34, p=0.734)$. Taken summarily, we conclude that managers who have high extrinsic motivation are more likely to manage earnings when compensation incentives are absent. These results confirm H3.

Table 3

Analysis of Intrinsic vs. Extrinsic Motivation Scores

Mean (SD)

\begin{tabular}{lccc}
\hline & \multicolumn{2}{c}{$\begin{array}{c}\text { Participants who managed earnings, } \\
\mathrm{n}=15\end{array}$} & $\begin{array}{c}\text { Participants who did not manage } \\
\text { earnings, } \mathrm{n}=7\end{array}$ \\
\cline { 2 - 3 } Extrinsic Score & $2.23(0.36)$ & $2.96(0.34)$ & \\
Intrinsic Score & $3.17(0.20)$ & $3.13(0.37)$ & $t=4.41, p<0.001$ \\
$t=-0.34, p<.734$ & \\
\hline
\end{tabular}

Scale $=1-4 ; 1=$ highest extrinsic motivation achievable, $4=$ highest intrinsic motivation achievable.

*All p-values are two-sided. 


\section{CONCLUSIONS}

We report the results of a $2 \times 2$ between-subjects design experiment to examine the effects of compensation incentives on earnings management, and specifically, whether internal motivation can explain why individuals manage earnings when such incentives are absent. We find that when compensation incentives are present, managers make earnings increasing (decreasing) decisions when current earnings are below (above) forecast. In the absence of compensation incentives however, we find that managers make earnings increasing decisions when current earnings are below forecast, but they do not make earnings decreasing decisions when current earnings are above forecast. Our analyses show that participants who manage earnings upwards, in the absence of compensation incentives, have an extrinsically-oriented motivation, compared to those who do not manage upwards. Individuals with strong extrinsic motivation are driven by concerns of evaluation, recognition, and competition (Amabile et al. 1994). We suggest that meeting the forecast creates a threshold for performance evaluation, provides the recognition of a 'job well done', and engages the competitive spirit of extrinsically-motivated participants. When current earnings are already above forecast, these individuals do not feel compelled to manage earnings as the evaluation threshold has already been reached and the 'game' has been won. Intrinsically-motivated individuals, on the other hand, are driven by their enjoyment, curiosity, and interest in a task for the sake of the task, not for any external recognition. Analysts' forecasts do not encourage this individual to engage in an action such as earnings management, absent compensation incentives. Our experiment held capital market pressure constant across all conditions. Thus, our study indicates that individual characteristics such as internal motivation play a role in earnings management above and beyond the two main drivers of earnings management identified in previous research: compensation and capital market concerns.

Our study makes several contributions: First, this research shows that managerial discretion and decision making can be understood further by examination at the individual level. Historically, managerial discretion and earnings management has been studied at the industry or firm level (e.g., Bloom and Milkovich, 1995; Finkelstein and Boyd, 1998; Zajac and Westphal, 1994). Second, this research adds to the compensation/earnings management literature, which has documented the existence of a relation between CEO bonus and earnings benchmarks. We add to this literature by providing evidence of individual traits that influence this relation. Finally, this study may be of interest to both regulators and investors as it provides evidence of the effects of linking bonuses to earnings benchmarks. Our results indicate that altering compensation incentives will not completely mitigate earnings management.

Our study is limited in that we do not provide participants with a full set of financial documents, which would likely be available to managers. Additionally, managers typically have a variety of ways to manipulate income (earnings). We only analyze one means of earnings management, revenue recognition. Future research should examine how managers use other means of earnings management individually and/or jointly. Although there are various forms of compensation incentives, we only use one type of compensation incentive (bonus plan). Future research could analyze how different types of compensation incentives affect managerial discretion and decision making.

Second, this experiment uses MBA students as surrogates for professional managers. It is likely that they have less experience than many professional managers and therefore their actions may not accurately reflect the opinions of managers. Integrative complexity is defined as the ability to draw relatively simple connections between distinct characteristics of the information set and make subsequent judgments and decisions. Participants in this study had an average of 5.3 years of current work experience. While the task in this study would likely be considered low in integrative complexity, it is possible that the decisions of participants in this study could differ from those of professional seasoned managers.

\section{AUTHOR INFORMATION}

Wendy W. Achilles, Ph.D., Associate Professor, Business Division, NC Wesleyan College, 3400 N. Wesleyan Blvd., Rocky Mount, NC, 27804. Email: wachilles@ncwc.edu, (W) 252-985-5272. She holds a Ph.D. in Accounting from Virginia Commonwealth University and a MSA/BSA from East Carolina University. Her research interest is accounting education. 
Jennifer Blaskovich, PhD., CPA, Associate Professor at the University of Nebraska - Omaha. She holds a PhD from the University of Nebraska - Lincoln. Jennifer researches judgment and decision-making issues with accountants and accounting information. She can be reached at jblaskovich@unomaha.edu, (W) 402-554-3984. (Corresponding author)

Terence J. Pitre, Ph.D., Assistant Professor, Opus College of Business, Department of Accounting, University of St. Thomas, 1000 LaSalle Ave. Minneapolis, MN 55403. Email: Tjpitre@ stthomas.edu, (W) 651-962-4246. He holds a Ph.D. in Accounting from Michigan State University, a Master in Business Administration from Tulane University and Bachelor of Science from the U. of Louisiana-Lafayette. His research interest is in investor decision making.

\section{REFERENCES}

1. Amabile, T., K. Hill, B. Hennessey, and E. Tighe. 1994. The Work Preference Inventory: Assessing intrinsic and extrinsic motivational orientations. Journal of Personality and Social Psychology 66 (5): 950967.

2. Baker, T., D. Collins, and A. Reitenga. 2009. Incentives and opportunities to manage earnings around option grants. Contemporary Accounting Research 26 (3): 649-672.

3. Bartov, E., E.Givoly, and C. Hayn. 2002. The rewards to meeting or beating earnings expectations. Journal of Accounting and Economics. 33 (2): 173-204.

4. Bloom, M., and G. Milkovich. 1995. Issues in managerial compensation research. CAHRS Working Paper \#95-24. Ithica, NY: Cornell University

5. Bowen, R., E. Noreen, and J. Lacey. 1981. Determinants of the corporate decision to capitalize interest. Journal of Accounting and Economics 3: 151-179.

6. Brown, L. and M. Caylor. 2005. A temporal analysis of quarterly earnings thresholds: Propensities and valuation consequences. The Accounting Review 80 (2): 423-444.

7. Burgstahler, D. and I. Dichev. 1997. Earnings management to avoid earnings decreases and losses, Journal of Accounting and Economics, Vol. 24, pp. 11-126.

8. Carter, M., L. Lynch and S. Zechman. 2006. The relation between executive compensation and earnings management: Changes in the post-Sarbanes-Oxley era. Working paper.

9. Cheng, Q., and T. Warfield. 2005. Equity incentives and earnings management. The Accounting Review 80 (2): 441-476.

10. Collins, D., M. Rozeff, and D. Dhaliwhal. 1981. The economic determinants of the market reaction to proposed mandatory accounting changes in the oil and gas industry: A cross-sectional analysis. Journal of Accounting and Economics 3: 37-72.

11. Cloyd, C., J. Pratt, and T. Stock. 1996. The use of financial accounting choice to support aggressive tax positions: Public and private firms. Journal of Accounting Research 34 (1): 23-44.

12. Das, S., P.K. Shroff, and H. Zhang. 2009. Quarterly earnings patterns and earnings management. Contemporary Accounting Research 26 (3): 797-831.

13. Dechow, P., S. Richardson, and I. Tuna. 2003. Why are earnings kinky? An examination of the earnings management explanation. Review of Accounting Studies 8: 355-383.

14. Deci, E., and R. Ryan. 1985. Intrinsic Motivation and Self-Determination in Human Behavior. New York: Plenum.

15. Deci, E. 1976. The hidden costs of rewards. Organizational Dynamics 76 (3): 61-12.

16. DeFond, M., C. Park. 1997. Smoothing income in anticipation of future earnings. Journal of Accounting and Economics 23 (2): 115-139.

17. Degeorge, F., J. Patel, and R. Zeckhauser, 1999. Earnings management to exceed thresholds, Journal of Business, 72 (1): 1-33.

18. Finkelstein, S., and Boyd, B. K. 1998. How much does the CEO matter? The role of managerial discretion in the setting of CEO compensation. Academy of Management Journal 41: 179-199.

19. Goldman, E., and S.L. Slezak. 2006. An equilibrium model of incentive contracts in the presence of information manipulation. Journal of Financial Economics 80 (3): 603-626.

20. Graham, J., C. Harvey, and S. Rajgopal. 2006. Value destruction and financial reporting decisions. Financial Analysts Journal 62 (6): 27-39. 
21. Hagerman, R., and M. Zmijewski. 1979. Some economic determinants of accounting policy choice. Journal of Accounting and Economics 1: 141-162.

22. Hambrick, D., and S. Finkelstein. 1987. Managerial discretion: A bridge between polar views of organizations. In L. L. Cummings and B. M. Staw (Eds.), Research in Organizational Behavior 9: 369-406.

23. Healy, P., and J. Wahlen. 1999. A review of the earnings management literature and its implications for standard setting. Accounting Horizons, 13 (4): 365-383.

24. Healy, P. 1985. The effect of bonus schemes on accounting decisions. Journal of Accounting and Economics: $85-107$.

25. Holthausen, R. 1981. Evidence on the effect of bond covenants and management compensation contracts on the choice of accounting techniques: The case of the depreciation switch-back. Journal of Accounting and Economics 3: 73-109.

26. Hunton, J. E., R. Libby, and C. L. Mazza. 2006. Financial reporting transparency and earnings management. Accounting Review 81 (1):135-157.

27. Kasznik, R., and M. McNichols. 2002 Does meeting earnings expectations matter? Evidence from analyst forecast revisions and share prices. Journal of Accounting Research 40 (3): 727-759.

28. Kennedy, J., T. Mitchell, and S. Sefick. 1998. Disclosure of contingent environmental liabilities: Some unintended consequences? Journal of Accounting Research 36 (2): 257-277.

29. Koestner, R., M. Zuckerman, and J. Koestner. 1987. Praise, involvement, and intrinsic motivation. Journal of Personality and Social Psychology, 53: 383-390.

30. Levitt, Jr., A. 1998. The numbers game. CPA Journal (December): 14-18.

31. Matsunaga, S., and C.Park. 2001. The effect of missing a quarterly earnings benchmark on the CEO's annual bonus. Accounting Review 76 (3): 313.

32. Rawsthorne, L., and A. Elliot. 1999. Achievement goals and intrinsic motivation: A meta-analytic review. Personality and Social Psychology Review 3 (4): 326-344.

33. Schipper, K. 1989. Commentary on earnings management. Accounting Horizons 3 (4): 91-102.

34. Watts, R., and J. Zimmerman. 1978. Towards a positive theory of the determination of accounting standards. The Accounting Review, January: 112-134.

35. Zajac, E., and J. Westphal. 1994. The costs and benefits of managerial incentives and monitoring in large US corporations: When is more not better? Strategic Management Journal 15: 121-142.

36. Zmijewski, M., and R. Hagerman. 1981. An income strategy approach to the positive theory of accounting standard setting/choice. Journal of Accounting and Economics 3:129-149. 


\section{NOTES}

